\title{
DOI: 10.7596/taksad.v10i2.3038
}

Citation: Özer, L., \& Özdek, A. (2021). Halk Müziği Eğitiminin Öğrencilerin Sosyal ve Kişisel Gelişimleri Üzerindeki Etkisi: Yurtdışında Yaşayan Türk Öğrenciler Üzerine Bir Araştırma. Journal of History Culture and Art Research, 10(2), 39-54. doi: http://dx.doi.org/10.7596/taksad.v10i2.3038

\section{The Effect of Folk Music Education on The Social and Personal Development of Students: A Case Study on Turkish Students Living Abroad}

\author{
Halk Müziği Eğitiminin Öğrencilerin Sosyal ve Kişisel Gelişimleri Üzerindeki Etkisi: \\ Yurtdışında Yaşayan Türk Öğrenciler Üzerine Bir Araştırma
}

Levent Özer ${ }^{1}$, Attila Özdek ${ }^{2}$

\begin{abstract}
It has been demonstrated by various researchers that music and music education not only contribute to the social and personal development of individuals but also have many positive effects on both physical and emotional development. Besides, it is known that the negative effects of adolescence to be reduced through music and music education and that individuals studying music and/or instruments can cope well with this ups-and-downs period. Through a music education that includes multifaceted acquisition goals for individuals during adolescence, it is believed that contributions can be made in various areas. This study, which was carried out in Bishkek, Kyrgyzstan, aims to determine the social and personal gain of adolescent students living abroad and the extent that they can contribute themselves dealing with the stress and difficulties through instrument education and teaching folk song. In this research, where descriptive and qualitative approaches are at the forefront, to determine the pre/post study status of students in their social and personal development "Program Effects Case Study" and "Critical Event case study" methods and techniques have been preferred. The sample of the study, who were in early adolescence, consisted of 7th and 8th class students. For the study, a special 15-week 30-hour instrument teaching lesson plan and a repertoire of folk music melodies have been prepared. Classes were held in three groups with a total of nine students. To determine the effects of the study on students, interviews were conducted with the help of forms consisting of open-ended questions about the students' pre/post-study status with themselves and their social environment. In the light of these findings, it was observed that there were advances in the social and personal development of students and the negative effects of early adolescence were decreased.
\end{abstract}

Keywords: Turkish Folk Music, Instrument Education, Baglama, Folk Song, Early Adolescence, Music Education Abroad.

\footnotetext{
${ }^{1}$ Müzik Öğretmeni, T.C. Dışişleri Bakanlığı Bişkek Büyükelçiliği Eğitim Müşavirliği, Bişkek Türk Okulu, ORCID: 0000-0003-4286-3712, E-mail: tempolevo@hotmail.com

2 Doç. Dr., Necmettin Erbakan Üniversitesi, Ahmet Keleşoğlu Eğitim Fakültesi, Güzel Sanatlar Eğitimi Bölümü, Müzik Eğitimi Anabilim Dalı, ORCID: 0000-0001-7214-5928, E-mail: argor73@hotmail.com
} 
Müziğin ve müzik eğitiminin bireylerin sosyal ve kişisel gelişimlerine katkı sağladığı, hem fiziksel hem de duygusal gelişimleri üzerinde birçok olumlu etkileri olduğu çeşitli araştırmacılar tarafından ortaya konulmuştur. Bunun yanı sıra müzik ve müzik eğitimi yoluyla ergenlik döneminin olumsuz etkilerinin azaldığı, müzik ve/veya çalgı eğitimi alan bireylerin bu iniş çıkışlı süreçle daha iyi başa çıkabildikleri bilinmektedir. Ergenlik dönemi içerisindeki bireylere çok yönlü kazanım hedeflerini içerisinde barındıran bir müzik eğitimi yoluyla çeşitli alanlarda katkılar sağlanabileceği düşünülmektedir. Kırgızistan Bişkek örneği üzerinden gerçekleştirilen bu çalışma ile enstrüman ve türkü öğretimi yoluyla yurt dışında yaşayan ergenlik dönemindeki öğrencilerin edinebilecekleri sosyal ve kişisel kazanımların neler olabileceğinin ve bu dönemde yaşanabilecek stres ve zorluklar ile başa çıkılmasına ne tür katkılar sağlanabileceğinin tespit edilmesi amaçlanmıştır. Betimsel ve nitel yaklaşımların ön planda olduğu bu araştırmada, öğrencilerin sosyal ve kişisel gelişimlerinde çalışma öncesi/sonrası durumlarının ortaya konulması adına "Program Etkisine Dayalı Durum Çalışması" ve yapılan çalışmanın örnekleminin, Kırgızistan Bişkek'te yaşayan erken ergenlik dönemindeki öğrenciler olması nedeniyle "Kritik Olay Durum Çalışması" yöntem ve teknikleri tercih edilmiştir. Çalışmanın örneklemini oluşturan grup üyeleri, uzmanlar tarafından erken ergenlik dönemi içerisinde kabul edilen 7 ve 8. Sınıf öğrencileri arasından seçilmiştir. Çalışma için özel olarak 15 hafta 30 saatlik özel bir enstrüman öğretimi ders planı ve halk müziği ezgileri repertuvarı oluşturulmuştur. Dersler üçerli gruplar halinde toplamda dokuz öğrenci ile gerçekleştirilmiştir. Çalışmanın öğrenciler üzerindeki etkilerinin ortaya konulabilmesi adına, öğrencilerin çalışma öncesi/sonrası durumları hakkında kendileri ve sosyal çevreleri ile açık uçlu sorulardan oluşan formlar yardımıyla görüşmeler yapılmıştır. Bu bulgular ışığında; çalışma ile öğrencilerde sosyal ve kişisel gelişim alanlarında ilerlemeler olduğu ve erken ergenlik döneminin olumsuz etkilerinin azalmasına katkı sağlanabildiği gözlemlenmiştir.

Anahtar Kelimeler: Türk Halk Müziği, Çalgı Eğitimi, Bağlama, Türkü, Erken Ergenlik Dönemi, Yurtdışında Müzik Eğitimi.

\section{Giriş}

Müzik eğitiminin özellikle ergenlik dönemi içerisinde yer alan bireyler üzerindeki etkilerini inceleyen bu araştırmada, kişilik ve kişiliği şekillendiren/etkileyen unsurlar ve ergenlik döneminin bireyler üzerindeki etkilerinin neler olduğu incelenmiştir.

Bireylerde kişilik kavramının kalıtsal ve çevresel faktörlerden etkilenen, doğumdan itibaren hayat boyu değişen/gelişen bir olgu olduğu ifade edilmektedir. Özdemir ve ark. (2012)'a göre kişilik kavramına ilişkin birtakım özellikler şu şekildedir:

Doğuştan gelen genetik özellikler ve çevresel faktörlerin etkileşimi uzun bir büyüme-gelişme sürecinde kendine özgü bir kişilik ortaya çıkarmaktadır. Kişilik gelişiminin bazı yönleri kalıtımdan bazı yönleri de çevreden etkilenirken, birçok yönü ise her ikisinden de etkilenmektedir. Genetik etkenler daha çok çocuğun potansiyelinin belirlenmesinde ön planda iken, çevresel faktörler de bu potansiyelin kullanımına yöneliktir.

Görüldüğü üzere çevresel faktörlerin kişiliğin gelişimindeki etkisi yadsınamaz ölçüdedir. Bu çalışmada bağlama/saz eğitimi ve Türk halk müziği ezgileri yoluyla yurt dışında yaşayan ve eğitim gören Türk ortaokul öğrencilerinin sosyal ve kişisel gelişimlerinde yaşadıkları "yabancı sosyal çevrenin" olumsuz etkilerini azaltabilecek, sosyal ve etkin bir öğrenme ortamının hazırlanması hedeflenmiştir.

Kişiliğin oluşup geliştiği geniş zamana yayılan süreç içerisinde, bazı kritik dönemlerin olduğu insan davranışları üzerinde çalışmalar yapan bilim insanları tarafından ortaya konulmuştur. Bu dönemlerden birisi de ergenlik döneminin ilk evresi olan "erken ergenlik" dönemidir. "Ergenlik dönemi psikososyal 
gelişim açısından, erken, orta ve geç ergenlik dönemi olmak üzere üç bölümde ele alınır. Erken ergenlik, 10-14 yaşlar arası dönemdir" (Aktaran: Parlaz ve ark. 2012: 11). Bilindiği üzere ergenlik dönemi içerisinde olan bireylerin hal tutum ve davranışlarında gözlemlenebilir birtakım olumsuz değişiklikler meydana gelebilmektedir. "Arıkan (2002)'a göre; bu dönemde çocuk yalnızlık isteği duyar, arkadaşlarılyla sık sık küser, gruptan kopar, ev yaşamındaki etkinliklere karışmak istemez ve daima kaygılı olur" (Aktaran: Apaydınlı, 2012:124). Bu kaygılı sürecin daha rahat geçirilebilmesi adına ailelerin ve öğretmenlerin bu çocukların içerisinde bulundukları sürecin hassasiyetinin bilincinde olmaları önemlidir. Ayrıca özellikle yurtdışında yaşayan öğrenciler için yabancı sosyal çevrenin muhtemel olumsuz etkilerinin farkında olarak bu doğrultuda bazı önlemler alınmasının elzem olduğu düşünülmektedir.

Bu bölümde, bağlama/saz çalma ve türkü söyleme kapsamlı bir müzik eğitimi yoluyla yurt dışında yaşayan ergenlik dönemi içerisindeki Türk öğrencilerin sosyal ve kişisel gelişimlerine sağlanabilecek katkıların hangi alanlarda olabileceği hakkında bilgiler verilmiştir.

Arıkan'a (2002) göre; bu dönemde çocuk yalnızlık isteği duyar, arkadaşlarıyla sık sık küser, gruptan kopar, ev yaşamındaki etkinliklere karışmak istemez ve daima kaygılı olur.

Ergenlik dönemindeki öğrencilerin kişilik gelişimlerine katkı sağlanabilmesi ve kendilerini sosyal çevrelerinden soyutlamalarını önlemek adına spor ve sanat dalları gibi farklı yollarla bir topluma/topluluğa dâhil olabilecekleri, bireysel ya da grup içerisinde bir ürün/başarı ortaya koyabilecekleri etkinlikler için ortam hazırlamak sanat-spor eğitmenlerinin öncelikleri arasında yer almalıdır. "Müzik eğitim programları ergenlere, kendilerini ifade edebilecekleri, öz disiplin, azim ve sabır gibi yaşam becerileri kazanacakları güvenli yerler sağlar. Benlik algısı ve özgüvenini artırır. Ergenler arasında müzik, birleştirici bir güçtür, farklı zemin, yaş ve sosyal grupları bir araya getirebilir" (Birkan, 2014: 45). Özellikle kendilerini Türkiye'de "gurbetçi" yaşadıkları ülkede ise "yabancı" olarak hisseden kritik dönemdeki bu öğrenciler için bir takım ilave önlemlerin alınmasının ve bu doğrultuda çalışmalar yapılmasının gerekli olduğu düşünülmektedir. Koç (2004)'un Gelişim Psikolojisi Açısından Ergenlik Dönemi ve Genel Özellikleri adlı çalışmasına göre; "ergenlik dönemi süreci içerisinde fizyolojik ve cinsel gelişim, duygusal gelişim, ahlaki gelişim ve sosyal gelişim gibi olgular bulunmaktadır" (Koç, 2004, 231-236). Buna dayanarak, ergenlik dönemi içerisindeki öğrencilerin sosyal, kişisel ve duygusal gelişimlerinin sağlıklı gerçekleşebilmesi için, ilgili bireylerin mümkün olduğunca sosyal ortamlarda bulunmalarına imkân sağlanmasının faydalı bir eylem olduğu düşünülmektedir. Bu çalışmada bağlama/saz eğitimi ve türkü söyleme çalışmaları yoluyla bu sosyal ortamlara bir örnek oluşturmak amaçlanmıştır.

Illgili amaca yönelik olarak çeşitli kaynaklar incelenip uzman görüşlerinden faydalanılarak bir bağlama/saz eğitimi planı ve Türk halk müziği ezgileri repertuvarı oluşturulmuştur. Gerçekleştirilen çalışma, öğrencilere yoğun ve üst düzey bir çalgı/repertuvar eğitimi verme amacı taşımamaktadır. Buradaki asıl hedef müzik eğitimi yoluyla, öğrencilerin sosyal ve kişisel gelişimlerini destekleyici kazanımlar elde edebilmeleri ve ergenlik döneminin olumsuz etkilerini atlatmalarına katkı sağlamak için, bireysel ve grup içerisinde gerçekleştirilen sosyal ve kültürel faaliyet ortamları hazırlamaktır.

Balkıs ve diğerlerine (2005) göre; ergenleri yaşadıkları veya yaşayacakları sıkıntılara karşı bilgilendirmek ve durumun farkında olmalarını sağlamak, aynı zamanda kişiliklerine göre farklı beceriler kazandırmak gerekmektedir. Öğrencilerin ilgi, yetenek ve istekleri doğrultusunda sosyal ve kültürel etkinliklere yönelmeleri için rehberlik edilmeli ve böylece özgüvenlerinin artması sağlanmalıdır.

\section{Problem Durumu}

Sosyal çevre en basit ifadeyle; kişinin etkileşim içerisinde bulunduğu ortam ve kişiler olarak tanımlanabilir. Anavatanlarından uzakta yaşamını sürdüren, içerisinde bulundukları toplum ve kültür 
için birer "yabancı" olan bireylerin, kişilik gelişiminin dönüm noktalarından birisi olarak nitelendirilebilen ergenlik dönemi sürecinde özellikle "toplumsal uyum sorunları" konusunda, kendi ülkelerinde yaşayan akranlarına kıyasla daha fazla sorun yaşayabileceğini tahmin ve ifade etmek yanlış olmaz. Ergenlik dönemi, belli bir yaşa/çağa gelmiş kişilerin tecrübe etmesi gereken zorunlu ve birçok açıdan birey üzerinde olumsuz yan etkileri olduğu bilinen bir süreç olarak bilinmektedir. Ergenlerde bu süreç içerisinde; bir amacı/hedefi olmamak, içine kapanıklık, odaklanma sorunları, sakarlık, isteksizlik, sorumluluk almaktan kaçınma, asabilik, anne babadan uzaklaşma, kendini ifade edememe düşüncesi vb. gibi belirtiler görülebilir. Bu belirtilerin etnik köken açısından "yabancı" olarak görüldükleri bir sosyal çevrede daha yoğun görülebileceği olasıdır.

Yurt dışında yaşayan ergenlik dönemindeki bireylerin tecrübe ettiği bilinen bir diğer problem, kullanılan ortak dilin (ilgili bireyler açısından) yabancı dil olduğu bir sosyal çevredir. Öğrencilerin ergenlik döneminin getirdiği kendini ifade edememe kaygısı ve özgüven eksikliklerinin yanı sıra, "Türkçelerinin" de yetersiz olduğu düşüncesi ile okulda öğretmenleri ve okul idarecileri ile iletişime geçmekten ve soru sormaktan kaçındıkları durumlar gözlemlenmiştir. Hem aile içerisinde hem de sosyokültürel çevrelerinde multilingual (birden çok konuşma dili) bir ortam içerisinde olan öğrencilerin, Türkiye Türkçesi konuşma seviyelerinin Türkiye'de yaşayan akranlarına kıyasla yetersiz olduğu ve bu doğrultuda çeşitli önlemlerin alınmasının gerekli olduğu düşünülmektedir.

Yurtdışında yaşayan öğrencilerin sosyal ve kişisel gelişimlerine katkı sağlamayı amaç edinen bir eğitmenin, bulundukları "yabancı sosyokültürel çevrenin" farkında olarak öğrencilerini bu durumun onların sosyal ve kişisel gelişimleri üzerindeki olası etkileri hususunda bilinçlendirmesinin ve gerekli önlemleri almasının elzem olduğunu ifade etmek yanlış olmaz. Bu hususta alınacak önlem ve tedbirler ile bu sorunların en aza indirilebileceği ve ilgili bireylerin kişisel ve sosyal gelişimlerine önemli katkılar sağlanabileceği düşünülmektedir.

"Ergenleri yaşadıkları veya yaşayacakları sıkıntılara karşı bilgilendirmek ve durumun farkında olmalarını sağlamak, aynı zamanda kişiliklerine göre farklı beceriler kazandırmak gerekmektedir. Öğrencilerin ilgi, yetenek ve istekleri doğrultusunda sosyal ve kültürel etkinliklere yönelmeleri için rehberlik edilmeli ve böylece özgüvenlerinin artması sağlanmalıdır" (Balkıs, Duru ve Buluş, 2005: 8597).

Bir ulusun en önemli değerlerinin başında o ulusa ait müzik gelmektedir. Türk ulusu açısından bu müzik türünün Türk halk müziği olarak kabul edildiği ifade edilebilir. Türk halk müziğinin temel çalgısı olarak kabul edilen bağlamanın/sazın eğitimi ve "Türk'ü, anlatan türkülerin" seslendirilmesi yoluyla bireylerin kendilerini uluslarına daha yakın ve ait hissedebilecekleri düşünülebilir. Ergen bireylerin bu dönemde hissettikleri ait olma, bir olgunun parçası/üyesi olma ihtiyaçlarının, kendi uluslarından bireyler ile birlikte oldukları Türk halk müziği ezgileri ve bağlama/saz eğitimi yoluyla karşılanabileceği düşünülmektedir. "Aynı yaş grubundaki çocukların ve gençlerin sosyokültürel bağlamda değişim ve gelişim göstermelerinde, toplu müzik çalışmalarının etkisi ve önemi büyüktür. Müzik eğitimi yoluyla, sosyal bir insan olmanın gereğine inanan bireyler, bir müzik grubu içerisinde çeşitli çalışmalar yaparak, bunları etkinliğe dönüştürme gereksinimi duyarlar. Bu tür bir gereksinimi, aynı yaş gruplarının birlikteliğiyle yapılan müziksel çalışma ortamları önemli ölçüde karşılamaktadır” (Uslu, 2013: 197).

Türkiye'de yaşayan ergenlerin geleneksel Türk müziği ve çalgılarına ilişkin eğitim alma konusunda hem okullarındaki müzik öğretmenlerinin yürüttükleri koro, çalgı kursları vb. sosyal/kültürel etkinlikler hem de özengen müzik eğitimi olarak ifade edilen özel müzik kurslarından faydalanabilme konusunda yurt dışında yaşayan Türk akranlarına göre daha avantajlı durumda oldukları bilinmektedir. Durumun hassasiyetinin farkında olan T.C. Milli Eğitim Bakanlığı Avrupa Birliği Dış İşleri Genel Müdürlüğü yetkililerinin, ilgili problemin çözümüne yönelik olarak yurtdışına görevlendirilecek öğretmenler 
içerisinde, branş ayrımı yapılmaksızın Türk müziği çalgısı çalabilen ve çalgısı ile gittiği ülkelerde oradaki öğrenciler için ilave çalışmalar yapabilecek öğretmenlere öncelik tanıdığı çeşitli örneklerle ortadadır.

Ergenlik dönemindeki bireylerin yaşadıkları diğer sorunlar ise sakarlık ve odaklanma problemleridir. Hali hazırda zor bir süreç geçiren bu bireyler bir de buna ilaveten topluluk içerisinde küçük düşme ve utanma endişesi yaşadıkları ve sakarlık, dikkatsizlik ve bir şeyleri yanlış yapma kaygısı ile kendilerini geri planda tutmayı tercih ettikleri bilinmektedir. Yapılan çalışma ile senkronize nota okuma ve çalgı çalma egzersizlerinin bu bireylerin odaklanmalarına katkı sağlaması, çalışma sonunda gerçekleştirilen Türk halk müziği dinletisinin ise topluluk karşısında daha kendinden emin tavırlar sergilemelerine yardımcı olması amaçlanmıştır.

Yurt dışında yaşayan ve erken ergenlik dönemi içerisinde yer alan bireylerin bu dönemin zorluklarıyla başa çıkabilme ve kişisel-sosyal gelişimlerine katkı sağlanabilmesi adına, kendi kültürlerine ait bir çalgının eğitimini vermek ve bunu aynı ulusa mensup arkadaşları ile grup içerisinde aktif rol alabilecekleri bir etkinlik halinde uygulamak faydalı bir eylem olarak değerlendirilmektedir. Bu çalışma ile ergenlik döneminde içine kapanan ve yalnız kalmayı tercih eden öğrencilere gurup içerisinde arkadaşları ile işbirliği ve uyum içerisinde hareket etme kabiliyeti kazandırılabilir. Öte yandan sorumluluk almaktan kaçınan ve disiplinli çalışma konusunda eksiklikleri olan öğrencileri, "daha başarılı bir grup/grup üyesi" olabilme hususunda yönlendirip cesaretlendirerek, bu öğrencilerin daha organize, sorumluluk sahibi, mücadeleci ve hedefleri olan bireyler olabilmelerine katkı sağlanabilir. Öğrencilerin bağlama/saz eğitimi ve Türk halk müziği ezgilerinin vokal icrası çalışmaları yoluyla müzikal yetenekleri üzerinden yaratıcılık ve özgüvenlerinin gelişmesine katkı sağlamak bu çalışmanın kazanım hedefleri arasındadır. Kazanmış oldukları yaratıcı yetenekler, bir topluluğun üyesi olma, gruba liderlik etme deneyimi ve özgüvenlerinin gelişmesi sonucunda, bu öğrencilerin ergenlik dönemini en hafif şekilde atlatarak geleceğe sağlıklı bireyler olarak adım atabilecekleri ön görülmüştür. "Müzik eğitimi alan bireylerde olumlu davranışlar sergileme, hayatlarını daha iyi organize etme, daha az kaygı, olumlu ruhsal gelişim, yaratıcılık ve sosyal gelişim alanlarında olumlu değişiklikler meydana gelmektedir". (Uluğbay, 2013: 1030).

Bağlama/saz eğitimi ve Türk halk müziği ezgilerinin sözlü icrası yoluyla yurtdışında yaşayan ergenlik dönemindeki öğrencilere sağlanabileceği düşünülen katkılar ana başlıklar halinde şu şekildedir:

- Aidiyet ihtiyaçlarının karşılayabilecekleri grup çalışma ortamı oluşturmak,

- Iş̧irlikçi öğrenme ve gruplar arası mücadele ortamları hazırlayarak özgüvenlerinin artmasına katkı sağlamak,

○ Türkiye Türkçesi gelişimleri ve kendilerini ifade edebilmelerine katkı sağlamak,

- Bilinçli müzik dinleyicisi olmaya yönlendirerek psikolojilerini olumsuz yönde etkileyebilecek müzik türlerinden kaçınmalarına katkı sağlamak,

- Zihin-beden koordinasyonlarına katkı sağlamak,

- Sosyal çevresiyle olan ilişkilerine katkı sağlamak.

Bu bölümde yukarıda verilen başıklara ilişkin açıklama ve ifadelere yer verilmiştir.

Grup ile gerçekleştirilen bağlama/saz eğitimi yoluyla yurtdışındaki öğrencilerin sosyal ve kişisel kazanımlarının yanı sıra, ergenlerin bu dönemde ihtiyaç duydukları "bir topluma/gruba ait hissetme" gereksinimlerini tatmin edebilmelerine olanak sağlanabileceği düşünülmüştür. Çalışmaya katılan öğrenciler her ne kadar evde ve okulda (büyük çoğunluğunu Türk öğrencilerin oluşturduğu Bişkek Türk Okulu) ait oldukları ulusun mensupları ile birlikte olsalar da, yaşadıkları diğer sosyal çevre için azınlık durumundadırlar. Bilim insanları bireyin kişiliğinin sağlıklı yönde gelişebilmesi için bazı şartların yerine getirilmesinin gerekliliği üzerinde durmuşlardır. Maslow'un ihtiyaçlar hiyerarşisinde fizyolojik ihtiyaçlar ve güvenlik ihtiyaçlarından hemen sonra üçüncü sırada "ait olma ve sevgi ihtiyaçları" bulunmaktadır (Aktaran: Tekke ve Coşkun, 2019: 793). 


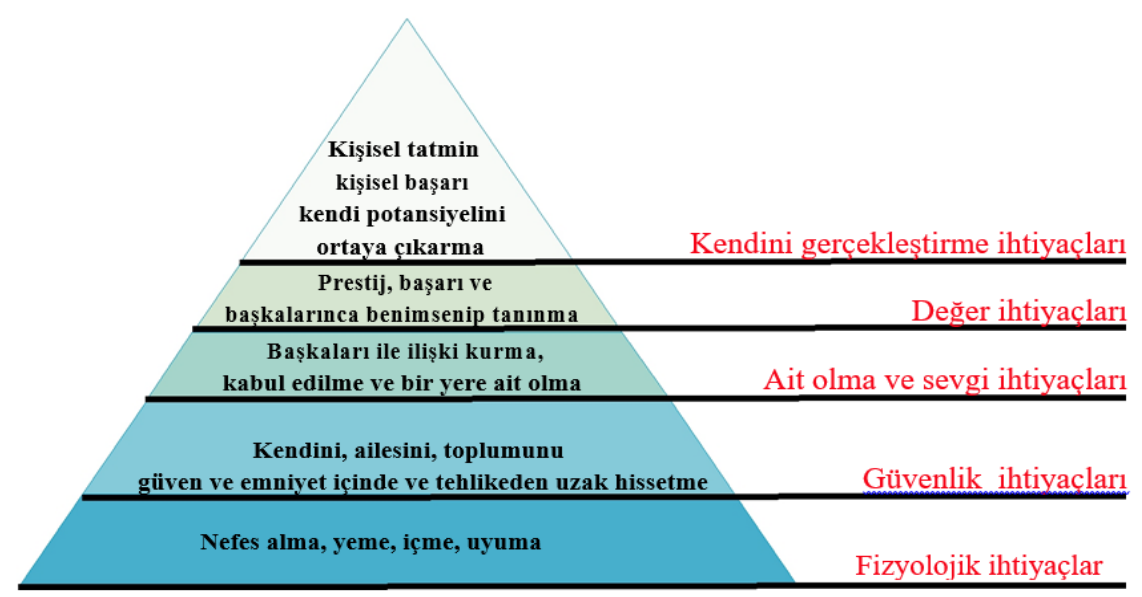

Görsel-1: Maslow'un ihtiyaçlar Hiyerarşisi Piramidi

Yapılan bu çalışma ile, özellikle "ait olma intiyacı" hususunda yurt dışında yaşayan bu öğrencilerin Türk kültürünün temel çalgılarından biri olan bağlama/saz çalmayı öğrenerek kendi vatan ve milletlerine daha yakın ve ait hissetmelerine katkı sağlanması amaçlanmıştır.

Müzik ve çalgı eğitimi her ne kadar planlı/programlı ve disiplinli bir şekilde yürütülmesi gereken bir yaklaşım gerektirse de bu süreç aynı zamanda eğlencelidir. Arkadaşları ile birlikte ezgiler çalıp söyleyen ve bu süreç içerisinde hem eğitici hem eğlenceli aktiviteler gerçekleştiren öğrencilerin ruh hallerinde olumlu değişiklikler olacağı ön görülmüştür. Nitekim çalışma sürecinde bu dokuz öğrenci üçerli gruplar halinde 3 ayrı takım oluşturmuş olup her grup kendi içerisinde, sonrasında ise bütün gruplar bir araya gelerek senkronize çalma ve söyleyebilme gibi hususlarda başarılı olabilmek adına çaba gösterdikleri görülmüştür.

“(Wismath ve Orr) 2015’e göre; İşbirlikli öğrenme; öğretme sürecindeki etkinliklerde öğretmen ile öğrenciler arasındaki, ayrıca öğrencilerin kendi aralarındaki etkileşimli işbirliği üzerine vurgu yapar. Bu eğitim stratejisi öğrencileri yaşam boyu öğrenen, kendi kendine karar verebilen ve özerk bireyler haline getirmeyi amaçlamaktadır" (Aktaran: Ökmen ve ark. 2019: 255).

İçerisinde eğlenceli etkinlikleri de barındıran bir bağlama/saz eğitim planı ile öğrencilerin bedensel, zihinsel ve dilsel becerileri arasında bir koordinasyon oluşarak bu alanların hepsinde kazanımlar elde edilebildikleri düşünülmektedir. "Farklı çalışmalardan elde edilen verilere göre genel olarak, bir çocuğun müziğe aktif katılımının onların üzerinde çeşitli etkileri olabilir. Bunlar algısal beceriler, dil ve okuryazarlık becerileri, aritmetik (matematiksel) beceriler, entelektüel gelişim, genel başarı ve yaratıcılık, kişisel ve sosyal gelişim, fiziksel gelişim ve sağlık gelişimi” (Azizinezhad, Hashemi, Darvishi, 2013:142). Çalışmada yer alan Türk halk müziği ezgilerinin zengin dilsel/edebi içerikleri ile yurt dışında yaşayan ve erken ergenlik dönemi içerisinde kabul edilen bu öğrencilere dil becerilerini (Türkçe telaffuz ve okur-yazarlık), geliştirmeleri hususunda katkı sağlanabileceği düşünülmüştür. Müziğin şarkılar yoluyla kelime dağarı, dil bilgisi kuralları, doğru telaffuz gibi yetileri geliştirme gücü bulunmaktadır (Vural, 2019:127).

Ortak görüşe göre ergenlik döneminin belirtilerinden bir tanesi de çekingenlik sebebiyle kendisini sözel olarak ifade etmekte zorluk yaşamaktır. Kırgızistan-Bişkek örneğinde sosyal çevrede kullanılan ortak dil (diller) Kırgızca ve Rusçadır. Çalışmaya katılan öğrencilerin büyük bir çoğunluğu günlük sosyal yaşamlarında bu hâkim iki dili, sadece evde ya da okulda Türkiye Türkçesi dilini kullanmakta oldukları bilinmektedir. Bu sebeple Türkçe dil yeterlilikleri Türkiye'de ki akranlarına kıyasla eksik kalmakta olup bu durumun özellikle okulda öğretmen, idarecileri ve Türkiye'de uzun süre vakit geçirmiş ve Türkçeyi 
düzgün kullanan sınıf-okul arkadaşları ile iletişim sorunları yaşamalarına sebep olduğu bilinmektedir. Yapılan çalışma sonucunda öğrencilerin belli bir oranda Türkiye Türkçesi kelime haznelerinin artmış olduğu, Türkçeyi doğru kullanma, telaffuz etme ve kendilerini ifade edebilme hususunda olumlu gelişmeler olduğu gözlemlenmiştir.

Öğrencilerin hem artan özgüvenleri hem de çalışma repertuvarında yer alan ezgilerin sözlerinden öğrendikleri yeni Türkçe kelimeler ile duygu ve düşüncelerini otoriteler (öğretmen, okul idarecileri vb.) ve topluluk karşısında sözlü olarak daha rahat ve zengin bir kelime dağarcığıyla ifade edebilecekleri ön görülmüştür.

Ergenlik dönemindeki bireylerin alışkanlıkları arasında kulaklıkla müzik dinlemenin de yer aldığı gözlemlenmiştir. Bu durum öğrencinin ailesi ve sosyal çevresi tarafından ne tür müzikler dinlediğinin bilinmesini olanaksız hale getirebilmektedir. Dinlenen müziklerin birey üzerinde psikolojik etki bıraktığı düşünüldüğünde, bağlama/saz eğitimi sürecinde kullanılan repertuvar, öğrencilere Türk halk müziğin tanıtmayı ve sevdirmeyi amaçlayarak, psikolojilerine zarar verebilecek ve onları karamsarlığa itecek türde müzikleri dinlemekten kaçınmalarına yardımcı olabileceği düşüncesi ile oluşturulmuştur. "Umutsuzluk, karamsarlık, kıskançlık gibi psikolojik sorunlar ortaya çıkaran müziklerin birey ve toplum üzerindeki olumsuz etkilerini azaltmak ya da yok etmek, aile içinden ve okul öncesi eğitim kurumlarından başlayarak devam eden "müzik eğitimi" ile gerçekleşebilir" (Öz, 2001: 104).

Ergenlik döneminin olumsuz etkilerinden birisi de sakarlıktır. Bu durumun ergen birey için önemli olan okul, sınıf ya da arkadaş ortamında yaşanması, ergenin kendisinin "gülünç" duruma düştüğünü hissederek öz güveninin zedelenmesine yol açabilir. "Ergenlik cinsiyet yeteneklerinin kazanıldığı dönemdir. Bu dönemde fiziksel gelişsme ve değişme oldukça hızlıdır. Boy ve kilo artışının yanı sıra bu dönemde iç organlar ve iskelet hızla büyümekte, kas dokusu gelişmekte ve yağ dokusu artmaktadır. Önce el ve ayakların büyümesi hızlanmakta, sonra önkol ve bacaklar daha sonra üst kol ve uyluklar uzamaktadır. Bu nedenle bu dönemde çok fazla sakarlıklar görülmektedir" (Alisinanoğlu, 2002: 62). Fizyolojik olarak gelişim sürecinde olan ergenler için, çalgı eğitimi gibi zihin/beden koordinasyonuna yönelik olumlu etkileri olduğu bilinen çalışmalar yapılmasının motor etkinlikler açısından faydaları olduğu bilinmekte olup, bu durumun olası sakarlık durumlarının azalmasında etkili olabileceği düşünülmektedir. "Müzikle herhangi bir şekilde ilgilenen ergenler bedensel olarak daha sağlıklı olarak, yaşıtlarıyla kıyaslandığında motor etkinliklerde daha hızlı gelişim göstermektedirler" (Oral, 2004: 57).

Anne babadan ve bazen de arkadaş çevresinden uzaklaşma ve onlarla olan iletişimin azalması ergenlik dönemindeki bireylerde görülebilen bir diğer davranıştır. Öğrenciler, çalışma sürecinde öğrendikleri ezgileri okulda arkadaşlarına ve evde ailelerine de çalıp söylemeleri ve öğrendikleri türkü hikâyelerini anlatmaları hususunda bilgilendirilip ödevlendirilmişlerdir. Bu durumun öğrencilerin sosyal çevreleri ve aileleri ile olan iletişimlerine katkı sağlayabileceği düşünülmüştür.

"Müziğin bireyler arasında bağ kurma, bireyin toplumsallaşmasını kolaylaştırıp hızlandırma, müzikli etkinlikler yoluyla grup çalışmalarına katılma, grubun üyesi olma, grubun içinde dikkat çekme, gruba kendini kabul ettirme, grubun içerisinde toplumsal güven kazanma gibi olumlu katıkları vardır" (Uçan, 1996: 21).

\section{Araştırmanın Problem Cümlesi ve Alt Problemleri}

Araştırmanın problem cümlesi "Yurtdışında yaşayan erken ergenlik dönemindeki Türk öğrencilerin bağlama/saz eğitimi ve türkü söyleme çalışmaları yoluyla elde edebileceği sosyal ve kişisel kazanımlar nelerdir?" şeklindedir.

Çalışmanın alt problemleri ise aşağıdaki gibidir: 
- Çalışmaya katılan öğrencilerin sosyal ve kişisel davranışlarında aileleri tarafından gözlemlenen değişiklikler nelerdir?

- Çalışmaya katılan öğrencilerin sosyal ve kişisel sosyal çevreleri tarafından gözlemlenen değişiklikler nelerdir?

- Çalışmaya katılan öğrencilerin sosyal ve kişisel davranışlarındaki değiş̧iklikler konusunda farkındalıkları ne boyuttadır?

\section{Araştırmanın Amacı ve Önemi}

Bu araştırma, yurtdışına yaşayan Türk ortaokul öğrencilerinin bağlama/saz eğitimi ve Türk halk müziği ezgilerinin sözlü icrası ile elde edecekleri sosyal ve kişisel kazanımların neler olabileceğinin ve ergenlik döneminin olumsuz etkilerinin azalmasına katkı sağlanabilirliğinin tespit edilebilmesini amaçlamaktadır.

Araştırma, Türkiye'deki benzerlerinden farklı olarak yurt dışında yaşayan Türk öğrenciler ile gerçekleştirilmiştir. Bu bağlamda Kırgızistan/Bişkek örneği üzerinden yapılan bu çalışmanın, gelecekte farklı coğrafyalarda yapılabilecek benzer çalışmalara örnek teşkil etmesi ve elde edilen bulguların müzik bilimi ve eğitiminin çeşitli alan ve basamaklarında kullanılması mümkündür.

\section{Yöntem}

\section{Araştırma İçin Tercih Edilen Yöntem ve Teknikler}

Betimsel ve nitel içerikler barındıran bu araştırma bir durum çalışmasıdır. Çalışmada bulguları en sağlıklı şekilde ortaya koyabilmek adına, araştırmanın durum çalışmasının iki alt başlığı üzerinden yürütülmesi tercih edilmiştir. Çalışma sonrasında öğrencilerin edinebileceği kazanımları ifade edebilmek amacıyla "Programın Etkilerine Dayalı Durum Çalışması" ve yapılan çalışmanın sadece Kırgızistan Bişkek Türk Okulu 2018 güz dönemi 7 ve 8. sınıf öğrencileri arasından seçilen öğrenciler ile gerçekleştirilmesi sebebiyle "Kritik Olay Durum Çalışmaları" yöntem ve tekniklerinin bu çalışma için uygun araştırma yöntem ve teknikleri oldukları düşünülmüştür. "Creswell (2007) kimi araştırmacıların durum çalışmalarını bir yöntem olarak değil de neyin çalışılacağının seçimi olarak ifade ettiklerini belirtmiştir. Ayrıca kimilerine göre durum çalışmalarının, soruşturma stratejileri, yöntem ya da kapsamlı araştırma stratejisi olduğunu eklemiştir. Bu doğrultuda durum çalışmasını bir yöntem olarak gördüğünü belirterek şu şekilde tanımlamıştır; Araştırmacının zaman içerisinde sınırlandırılmış bir veya birkaç durumu çoklu kaynakları içeren veri toplama araçları (gözlemler, görüşmeler, görsel işitseller, dokümanlar, raporlar) ile derinlemesine incelediği durumların ve duruma bağı temaların tanımlandığı nitel bir araştırma yaklaşımı" (Aktaran, Yıldırım ve Bahçekapılı ve Bahçekapılı, 2011:2). Bu bağlamda özel olarak hazırlanan 10 derslik ön hazırlık/alıştırma süreci ve 20 türküyü kapsayan bağlama/saz ders planı ve ilgili Türk halk müziği ezgileri repertuvarı ile Kırgızistan'da yaşayan erken ergenlik dönemindeki Türk öğrencilerin sosyal ve kişisel bağlamda ne gibi kazanımlar elde edebilecekleri ve ergenlik döneminin olumsuz etkilerinin giderilmesine ne gibi katkılar sağlanabileceği ortaya konulmaya çalışılımıştır.

\section{Araştırmanın Ön Hazırlık Süreci}

Çalışma için kullanılacak bağlama/saz eğitim planı ve Türk halk müziği ezgileri repertuvarı belirlenirken alanında uzman ve deneyimli hocaların görüş, öneri ve onayları alınmıştır. Ayrıca bu alanda yapılmış benzer çalışmalar incelenmiş, ilgili çalışmalar arasında özellikle müzik eğitiminin bireylerin dilsel, sosyal ve kişisel gelişimi üzerindeki etkileri ile ergenlerde müzik eğitimi unsurunu içerisinde barındıran çalışmalar üzerinde durulmuş ve bu çalışmalardan faydalanılmıştır. Bütün bu ön araştırma ve hazırlık süreci sonrasında çalışma için uygun olabileceği düşünülen bağlama/saz öğretimi ders planı ve ilişkili Türk halk müziği ezgileri repertuvarı oluşturulmuştur. 


\section{Çalışmada Kullanılan Türk Halk Müziği Ezgileri Repertuvarı Belirlenirken Göz Önünde Bulundurulan Unsurlar}

“Maess \& Koelsch' in 2001 yılında yaptıkları çalışmasından elde edilen verilere göre nörolojistler müziksel işlemlerin ve dil ile ilgili işlemlerin beynin aynı bölgesinde gerçekleştiğini bulmuşlardır. Müziksel ve dilsel anlamlandırmanın paralellikler sergilediğini de belirtmişlerdir" (Aktaran: Nişancı, 2013:3). Bu bilgi ışığında beynin dil ile ilgili yapılan işlemler bölümünün müzik ve çalgı eğitimi yoluyla uyarılarak daha aktif hale getirilmesi ve bu durumu kelime öğrenimi ve doğru telaffuz lehine kullanılması amaçlanmıştır. Öğrencilerin çalışma sonucunda yeni öğrendikleri kelimeler ve daha önceden bildikleri ancak vurgulama ve telaffuzlarında yanlışlıklar yaptıkları kelimelerin büyük oranda düzeldiği ve Türkiye Türkçesini daha doğru kullanabildikleri gözlemlenmiştir.

Çalışma repertuvarını oluşturan türküler belirlenirken, türkülerin söz ve hikâyelerinin yurt dışında yaşayan öğrencilerin Türkçe kelime dağarcıklarına katkı sağlanması hususu göz önünde bulundurulmuştur. Bu bağlamda Türkiye'nin dört bir yanından farklı 17 yöreye ait, öğrencilerin seviyelerine uygun, sözlerinde yöresel ağız ve deyimleri de içerisinde barındıran türküler tercih edilmiştir.

Çalışmaya katılan öğrencilerin büyük çoğunluğu Türk babaya, Kırgız, Kazak ya da Rus anneye sahiptirler. Bu durumun ev ortamlarında birden çok dilin konuşulmasına ve Türkiye Türkçesinin çocukların dil gelişimleri için yeteri kadar kullanılmıyor olmasına sebebiyet verebildiği düşünülmektedir. Bu çalışma ile öğrencilere, Türkçeyi sıfırdan öğrenme aşamasında olmasalar dahi katkı sağlanabileceği düşünülmüştür. Çalışma repertuvarını oluşturan türküler ve türkü sözleri içerisinde geçen yöresel kelime ve deyimler aşağıdaki tabloda verilmiştir.

Tablo- 1:Çalışma Repertuvarını Oluşturan Türkülerin Yöreleri ve Bu Yörelere Özgü Kelime ve Deyimler

\begin{tabular}{|l|l|l|l|}
\hline & \multicolumn{1}{|c|}{ Türkünün Adı } & \multicolumn{1}{|c|}{ Yöre } & \multicolumn{1}{|c|}{ Kelime ve Deyimler } \\
\hline 1 & Hekimoğlu & Ordu & Uşak, Martin, Konak \\
\hline 2 & $\begin{array}{l}\text { Drama Köprüsünden Gece mi } \\
\text { Geçtin }\end{array}$ & Trakya & $\begin{array}{l}\text { Mahpus, Yardan Geçmek, Ecel Şerbeti, } \\
\text { Namı Yürümek }\end{array}$ \\
\hline 3 & Beni Hor Görme Gardaşım & Sivas & $\begin{array}{l}\text { Aynı Vardan Var Olmak, Nefsini Öldürmek, } \\
\text { Hor Görmek }\end{array}$ \\
\hline 4 & Burçak Tarlası & Tokat & $\begin{array}{l}\text { Deyyus, Evini Başına Yıkmak, Ömrü } \\
\text { Tükenmek, Intizar Eylemek }\end{array}$ \\
\hline 5 & Bitlis'te Beş Minare & Bitlis & Beri, Yüreği Yara Dolu Olmak \\
\hline 7 & Ata Barı & Artvin & Yadigâr, Alnına Yazılmak, Kevi \\
\hline 8 & Ah Bir Ataş Ver & Elazı̆̆ & Az Derdin Artması, Engellerin Uyanması \\
\hline 9 & Havada Bulut Yok & İzmir & Ataş, Cigara, Çatal Yürek, Gavur \\
\hline 10 & Yüksek Yüksek Tepelere & Muş & $\begin{array}{l}\text { Mehle, Figan, Yaman, Çemen, Acep, Redif, } \\
\text { Pabuç }\end{array}$ \\
\hline 11 & Ev Kurmasınlar & Edirne & Aşrı, Malum Olmak, Hor Görmek \\
\hline
\end{tabular}




\begin{tabular}{|l|l|l|l|}
\hline 12 & Ardahan'ın Yollarında & Kars & Bağ, Fayda Görmek \\
\hline 13 & Oynayın Gız Oynayın & Trabzon & Gız, Gayda, Temun \\
\hline 14 & Nar Danesi & Kırşehir & Dane, Gönüle Dolmak, Zülüf \\
\hline 15 & $\begin{array}{l}\text { İşte Gidiyorum } \\
\text { Çeşm-i Siyahım }\end{array}$ & $\begin{array}{l}\text { Kahraman } \\
\text { Maraş }\end{array}$ & $\begin{array}{l}\text { Çeşm-i Siyah, Baht, Zar, Viran, Elin Diline } \\
\text { Bırakmak, Parelenmek }\end{array}$ \\
\hline 16 & Çanakkale İ̧̧inde Aynalı Çarşı & Kastamonu & Duman Bürümek, Fırka, Selvi \\
\hline 17 & Bülbülüm Altın Kafeste & Rumeli & Aheste, Har \\
\hline 18 & Ordunun Dereleri & Ordu & Ellere Vermek, Üstüne Kalkmak \\
\hline 19 & Çarşambayı Sel Aldı & Samsun & $\begin{array}{l}\text { El aldı, Eli Koynunda Kalmak, Ateşten } \\
\text { Gömlek, Alnına Kara Yazı Yazılmak, Sevda } \\
\text { Çekmek }\end{array}$ \\
\hline 20 & Osman Paşa & Rumeli & Binler Yaşamak \\
\hline
\end{tabular}

Tabloda görüldüğü üzere çalışmada kullanılan türkülerin sözleri içerisinde yaklaşık olarak yetmiş yöresel kelime ve deyim bulunmaktadır. Bu deyim ve kelimelerin öğrencilerin sosyal çevreleri tarafından kullanılmadığı düşüncesi ile türküleri seslendirme çalışmaları sırasında bu kelimelerin anlamları öğrenciler ile paylaşılarak Türkçe kelime ve deyim dağarcıklarına katkı sağlanmaya çalışılmıştır.

\section{Çalışmada Kullanılan Veri Toplama Araçları}

Çalışmada kullanılan veri toplama araçları ve görüşme yapılan kişilere ait bilgilere geçilmeden önce çalışma grubunun fiziksel ve demografik özellikleri olarak nitelendirilebilecek; aile yapısı, yaş grubu, sınıfı, cinsiyeti ve bu cinsiyetlerin dağılımı vb. bilgilerin okuyucuyla paylaşılmasının uygun olduğu düşünülmüştür. Bu doğrultuda çalışmaya katılan öğrenciler;

Fiziksel hazırbulunuşluk seviyeleri birbirlerine yakın özellikler gösteren, en az 4-5 yıldır Kırgızistan'da yaşayan, tercihen çok kültür/uyruklu (yabancı uyruklu anne ve Türk uyruklu baba) aile yapısına mensup, yeterli seviyede müzikal yeteneğe sahip ilköğretim 7. ve 8. Sınıf öğrencileri arasından seçilmişlerdir. İlgili kriterleri sağlayan ve çalışmada gönüllü olarak yer alan öğrenciler 3 kız 6 erkek olmak üzere toplamda 9 öğrencidir.

Çalışmanın ilgili öğrencilerin sosyal ve kişisel gelişimleri üzerindeki etkilerini nitel olarak ifade edebilmeye yönelik olarak, öğrencilerin sosyal çevreleri ve kendileri ile çalışmanın hedeflenen kazanımlarına uygun olarak önceden belirlenen açık uçlu sorular üzerinden görüşmeler yapılmıştır. Görüşmeler, ilgili kişinin onayı ile ses-video kaydı ile gerçekleştirilerek daha sonra bu kayıtlar aslına uygun olarak dikte edilmiştir.

Yukarıda bahsedilen ve öğrencinin sosyal çevresini oluşturduğu düşünülerek görüşmeler yapılan bireylere ait bilgiler ve ilgili bireylere yöneltilen anket soruları şu şekildedir:

Her bir öğrenci için;

- Anne-baba (görüşmeye ikisi de davet edilmiş ancak çoğunlukla sadece biri gelmiştir.)

1. Çocuğunuzun kişisel tutum ve davranışlarında, çalışma öncesi/sonrası gözlemlediğiniz değişiklikler oldu mu? Varsa ifade ediniz.

2. Çocuğunuzun arkadaşları varsa kardeşleri ile iletişimlerinde, çalışma öncesi/sonrası gözlemlediğiniz değişiklikler oldu mu? Varsa ifade ediniz. 
3. Çocuğunuzun kendini ifade edebilmesi bağlamında, çalışma öncesi/sonrası gözlemlediğiniz değişiklikler oldu mu? Varsa ifade ediniz.

4. Çocuğunuzu ergenlik dönemi içerisinde kabul edecek olursak, bu sürecin zorluklarını (dikkatsizlik, çekingenlik, içine kapanıklık, sakarlık vb.) daha kolay atlatmada, çalışma öncesi/sonrası gözlemlediğiniz değişiklikler oldu mu? Varsa ifade ediniz.

5. Çocuğunuzun sizinle iletişimlerinde, çalışma öncesi/sonrası gözlemlediğiniz değişiklikler oldu mu? Varsa ifade ediniz.

\section{○ Sınıf arkadaşları (2 farklı arkadaş)}

1. Arkadaşınızın sizinle iletişimlerinde, çalışma öncesi/sonrası gözlemlediğiniz değişiklikler oldu mu? Varsa ifade ediniz.

2. Arkadaşınızın Türkçeyi düzgün kullanabilme ve kendisini ifade edebilme becerisinde, çalışma öncesi/sonrası gözlemlediğiniz değişiklikler oldu mu? Varsa ifade ediniz.

○Öğretmen ve idarecileri (Türkçe, matematik, fen bilimleri, sosyal bilimler, okul müdür yardımcısı)

1. Öğrencinin okulda ve dersiniz esnasındaki tutum ve davranış/arında, çalışma öncesi/sonrası gözlemlediğiniz değişiklikler oldu mu? Varsa ifade ediniz.

2. - Öğrencinin arkadaşları ile iletişimlerinde, çalışma öncesi/sonrası gözlemlediğiniz değişiklikler oldu mu? Varsa ifade ediniz.

3. Öğrencinin Türkçeyi düzgün kullanabilme ve kendini ifade edebilmesi bağlamında, çalışma öncesi/sonrası gözlemlediğiniz değişiklikler oldu mu? Varsa ifade ediniz.

\section{○ Okul rehber öğretmeni}

Okul rehber öğretmenine diğer öğretmenlere iletilen soruların yanı sıra öğrenciler ile bireysel olarak yaptığı görüşmeler üzerinden bir değerlendirme yapılması istenmiştir.

illgili öğrencilerin çalışmadan önceki ve sonraki durumları arasındaki gelişim ve değişiklikler, karşılaştırma analizi ile belirlenerek elde edilen veriler rapor haline getirilmiştir.

\section{Bulgular ve Yorumlar}

Bu bölümde görüşme verilerinden elden edilen bulgulara dayanarak çalışmanın ilgili öğrencilerin sosyal ve kişisel gelişimleri üzerindeki etkilerinden bahsedilmiştir.

Tekrarlardan kaçınmak adına görüşme yapılan bireylerin görüşleri ve öğrencilerin kendi hakkındaki değerlendirmelerine ait genel çıkarımlar, alt problemlere uygun olarak üç ana başlık altında sunulmuştur.

1. "Çalışmaya katılan öğrencilerin sosyal ve kişisel davranışlarında aileleri tarafından gözlemlenen değişiklikler nelerdir"?

Öğrencilerin aileleri ile yapılan görüşmeler sonucunda ortaya çıkan genel yargı, bu öğrencilerin çalışmaya katılmadan önceki durumları ile çalışma sonrası durumları arasında özgüven, sosyokültürel ilişkiler, Türkçeyi kullanma becerileri, kendilerini ifade edebilme, iletişim becerisi ve ergenlik döneminin olumsuz etkilerinin azalması konularında kayda değer olumlu değişiklikler olduğu yönündedir.

Serbest vakitlerini genellikle odalarında ya da dışarıda geçirmeyi tercih eden öğrencilerin aileleri ile daha yakın ilişkiler kurma çabası içerisinde oldukları gözlemlenmiştir. Aileleri tarafından önceleri utangaç, içine kapanık, sessiz ve kendi halindeydi gibi tabirlerle bahsedilen öğrencilerin çalışma sonrasında aileleri ile daha çok iletişime geçme, düşüncelerini eskiye nazaran daha çok paylaşma, 
bağlama/saz dersinde, okulda ya da dışarıda yaşadıkları olaylar hakkında konuşma hususlarında ilerleme kaydettikleri görülmüştür.

Çalışma sonucunda ergenlik döneminin belirtilerinden olan ani duygu değişimleri ve bu duyguların yoğunluk oranlarının çalışma öncesine nazaran önemli ölçüde azaldığı yine aileler tarafından ifade edilmiştir. Birden sinirlenen, duygusallaşan ya da sebepli sebepsiz üzülen öğrencilerin daha sakin, mutlu ve huzurlu tavırlar sergilediği aileler tarafından belirtilmiştir.

Ergenlik döneminin bir başka belirtisi olan sakarlık dikkatsizlik gibi konularda öğrencilerin çalışma öncesine nazaran vücut koordinasyonlarında olumlu değişiklikler olduğu, öğrencilerin bir şeylere çarpma, dökme, takılma konularında azalmalar olduğu belirtilmiştir. Genel yargıdan ayrı olarak küçükken ağaçtan düşen ve bunun sonucunda ellerinde istemsiz küçük kasılma ve titremeler olan bir öğrencinin bağlama/saz eğitimi aldıktan sonra bu kasılma ve titremelerinde azalmalar olduğu görülmüş bu durum da çalışmanın ön görülmeyen/hedeflenmeyen olumlu kazanımları arasında sayılmıştır.

Ailelerin gözlemlerine göre bir çalgıyı öğrenmesi ve onu çalmayı başarabilmesi çocuklarının özgüveninin artmasına ciddi katkılar sağlamıştır. Çocuklarından "bunu da başarabilirim, galiba bunu da yapabilirim" gibi kararlı ve azim dolu ifadeler duyduklarını ve bu durumdan oldukça hoşnut olduklarını belirtmişlerdir.

Aileler çalışmaya katılan öğrencilerin evde eskiye nazaran daha çok Türkçe konuştuklarını, çoğunlukla yabancı bir ulusa mensup olan annelerini ve kardeşlerini de Türkçe konuşmaya teşvik ettiklerini, yeni kelimeler öğrenmek adına serbest vakitlerinde eskiye nazaran daha çok Türk yapımı dizi, film vb. izlediklerini ve daha çok Türkçe müzik dinlediklerini ifade etmişlerdir.

Çok fazla arkadaşı olmayan, ya da arkadaşları ile vakit geçirmek yerine bilgisayar, telefon, tablet ve oyun konsolu gibi elektronik ürünler karşısında vakit geçirmeyi tercih eden öğrencilerin, özellikle aynı çalışma grubunda olduğu arkadaşlarıyla bir araya geldiği, hem çalgıları ve eserler üzerinde çalışmalar yaptıkları hem de birlikte oyun oynadıkları aileler tarafından ifade edilmiştir.

Çalışmanın aileler tarafından gözlemlenen bir diğer olumlu etkisi de çocuklarının yetişkin yakınları ile sosyalleşmesine katkı sağladığı yönündedir. Önceleri evlerine akrabaları ya da aile büyükleri geldiğinde odalarında kalan ya da ortam içerisinde sessiz kalan öğrencilerin, gelen misafirlere öğrendikleri türküleri seslendirdikleri, onlarla daha çok iletişimde bulundukları şeklindedir.

2. "Çalışmaya katılan öğrencilerin sosyal ve kişisel sosyal çevreleri tarafından gözlemlenen değişiklikler nelerdir"?

Çalışmaya katılan öğrencilerin sınıf arkadaşları, Türkçe, matematik, fen bilimleri, sosyal bilimler öğretmenleri, okul rehber öğretmeni ve okul müdür yardımcısı ile yapılan görüşmelerden ortaya çıkan genel yargı, çalışma sonucunda elde edilmesi öngörülen kazanımlara büyük oranda ulaşılabildiği yönündedir.

Çalışmaya katılan bireylerin okul ve sınıf ortamında eskiye nazaran daha çok sosyalleşen, var olan arkadaşları ile iletişimlerini güçlendirmenin yanı sıra yeni arkadaşlar edinen, düşüncelerini arkadaş çevresinde daha rahat ve özgüvenli bir şekilde ifade edebilen öğrenciler oldukları görülmüştür. Arkadaşlarının ifadelerine göre, herhangi bir tartışma ortamında sessiz kalan veya düşüncelerini asabi ya da savunmacı bir tavırla dile getiren öğrencilerin bu diyaloglarda daha sakin, saygılı ve kendinden emin tavırlar sergiledikleri görülmüştür.

Öğretmenlerin genel görüşü bu öğrencilerin çalışma süreci ve sonrasında dersle ya da başka konularla ilgili söz almaya eskiye nazaran daha istekli oldukları yönündedir. Öğretmenlere göre bu durum sanatla, müzikle ilgilenmeye başlayan ve bu konuda belli bir seviye ve başarıya ulaşan bu öğrencilerin okul sosyal çevresinin büyük çoğunluğuna göre kendilerini ayrıcalıklı ve farklı hissetmeleri ile kazandıkları öz güven ile ilişkilidir. 
Çalışma süreci ve sonunda kendilerini müzikal alanda yetenekli ve başarılı hisseden öğrencilerin, okulda hazırlanan/düzenlenen diğer sosyal ve kültürel etkinliklerde de eskiye nazaran daha çok görev almaya istekli oldukları öğretmenler tarafından ifade edilmiştir.

Başta Türkçe ders öğretmenleri olmak üzere birçok öğretmen çalışmaya katılan öğrencilerin Türkçeyi doğru kullanma ve telaffuz edebilme hususlarında gelişim gösterdiklerini ifade etmişlerdir.

Öğretmenler çalışmaya katılan ve özellikle aynı sınıfta yer alan öğrenciler arasında saz/bağlama çalmakta daha iyi olmak başta olmak üzere diğer konular ve derslerde de arkadaşından daha başarılı olabilmek adına kaybedeni olmayan bir rekabet içerisinde olduklarını gözlemlediklerini belirtmişlerdir. Bu durumun her öğrencinin daha azimli, planlı ve başarı hedefleri olan bireyler olmalarına katkı sağladığını ifade etmişlerdir.

Çalışmaya katılan öğrencilerin hepsi ile görüşmeler yapan okul rehberlik öğretmeninin öğrencilere ilişkin genel yargısı ise şu şekildedir:

Öğrenciler arasında daha önce ergenlik dönemi içerisinde yaşadığı zorluklardan dolayı bireysel terapi alan öğrenciler de bulunmaktadır. Bu dönemdeki öğrenciler genel olarak kaygı, sosyal fobi, topluluk karşısında huzursuz ve güvensiz hissetme ve kendini ifade edememe düşüncesi gibi problemleri olduğunu dile getirmektedirler. Yapılan çalışma ile başta bireysel terapi alan öğrenciler olmak üzere bütün öğrencilere kaygılandıkları konuların üstesinden gelme şansı tanınmış ve bu durumun üstesinden gelebilmelerine olanak sağlanmıştır. Çalışmanın bir grup içerisinde gerçekleşmiş olması ve çalışma sonunda sahnelenen dinletide görev almaları çocuklar üzerinde "maruz kalma etkisi" dediğimiz etkiyi gerçekleştirmiştir. Bu şekilde korktukları ve çekindikleri bir durum karşısında başarı elde etmeleri, arkadaşları ve öğretmenleri tarafından tebrik ve takdir edilmeleri onlara sosyalleşmenin ve etkinliklerde ön planda yer almanın aslında korkulacak bir şey olmadığını aksine kendilerini daha iyi hissetmeleri ve öz güvenlerinin artmasına vesile olacak durumlar olduğunu görmelerini sağlamıştır.

Önceleri okulda yapılacak tören ve etkinliklerde görev almaya gönüllü öğrenci bulmakta zorluklar yaşayan öğretmen ve idareciler, başta bu çalışmaya katılan öğrenciler ve bu öğrencilerin destekleyip cesaretlendirdiği arkadaşları sayesinde bu durumun değiştiğini ifade etmişlerdir.

\section{3. "Çalışmaya katılan öğrencilerin sosyal ve kişisel davranışlarındaki değişiklikler konusunda farkındalıkları ne boyuttadır"?}

Aşağıdaki ifadeler öğrenciler ile yapılan görüşmelerden ortaya çıkan bulgulara göre yorumlanmıştır.

Öğrencilerle çalışma süreci ve sonunda bireysel olarak yapılan görüşmeler sonucunda ortaya çıkan genel yargı, en sade ifade ile kendilerini daha mutlu hissettikleri yönündedir. Ergenlik döneminin kaygı ve endişelerinden büyük oranda arınmış, kendisine güvenen, sosyal ilişkiler kurmaktan ve düşüncelerini ifade etmekten çekinmeyen bireyler olma yönünde önemli gelişimler göstermişlerdir.

Yapılan çalışma için seçilen öğrenciler belli kriterleri karşılayan ve çalışma için gönüllü olan öğrenciler arasından ön eleme yolu ile seçilmişlerdir. Bu elemede başarılı olan ve çalışmada yer almaya hak kazanan öğrenciler, daha çalışmanın başında bile seçilebilmiş oldukları için kendilerini başarılı kabul ettiklerini ifade etmişlerdir.

Çalışmanın ilk dersinde bağlama/sazı tutmayı bile bilmeyen öğrenciler dersler ve haftalar ilerledikçe ezgiler çalabildiklerinde kendilerine olan inançlarının ve öz güvenlerinin artarak başka alanlarda da başarılı olabileceklerine inandıklarını ifade etmişleridir.

Aile ve sosyal çevreleri tarafından sessiz, içine kapanık ve çekingen gibi ifadeler ile tasvir edilen öğrenciler bu çalışma ile kendilerini daha iyi ifade edebilen, düşüncelerini söylemekten ya da görev almaktan kaçınmayan, hatta bu görevler için gönüllü olan ve mücadele eden bireyler haline gelmişlerdir. Bu durum için bir örnek vermek gerekirse çalışmaya katılmadan önce sınıfta en arka sırada oturan ve hiçbir konuda ön planda olmayan/olmak istemeyen bir öğrenci, bu çalışmanın 
tamamlanmasının ardından bir sonraki dönem sınıf başkanlığına aday olmuş ve arkadaşlarının oyunun büyük bir çoğunluğunu alarak sınıf başkanı seçilmiştir.

Başka bir öğrenci ise çalışmanın ön görülmeyen kazanımlarından biri olan fiziksel faydaları sayesinde ellerinin daha az titrediğini ve bu durumun çekingenliğinin ve utangaçlığının azalmasına ve bu konuda kendisini çok daha "rahat ve mutlu" hissetmesine vesile olduğunu ifade etmiştir.

Öğrenci gruplarının eserleri daha önce ve daha güzel seslendirebilme konusunda bir rekabete girdikleri ve bu durumu kendi aralarında eğlenceli bir yarışmaya/aktiviteye dönüştürdükleri gözlemlenmiştir. "Mücadele ruhu" ve "daha başarılı olma arzusu" gibi alışkanlıklar edindiği düşünülen öğrencilerin bu yönlerini farklı alanlarda da sergileyerek, girdikleri ortamlarda söz sahibi olma ve liderlik etme gibi eğilimlerde bulundukları gözlemlenmiştir.

Çalışma öncesinde seçmeleri kazanana kadar müzik yeteneğinin farkında olmayan öğrenciler bu yeteneklerinin varlığını öğrenmeleri sonucunda farklı sosyal ve kültürel alanlarda da başarılı olma isteği ve heyecanı duyarak halk oyunları ve tiyatro gibi faaliyetlerde de görevler almışlardır. Bu durum, çalışma sonrasında öğrencilerin sosyalleşme ve öz güven konularında önemli gelişmeler gösterdiklerine başka bir örnek olarak kabul edilebilir.

\section{Sonuç ve Öneriler}

Bağlama/saz eğitimi ve Türk halk müziği ezgilerinin vokal icrası çalışmaları yoluyla yurtdışında yaşayan ergenlik dönemindeki öğrencilerin elde edilebildikleri düşünülen kazanımlar şu şekildedir;

Sosyal ve kişisel davranış ve alışkanlıkları ile sosyal ilişkilerinde olumlu gelişmeler meydana gelmiştir.

Kazandıkları özgüven, öğrendikleri yeni Türkçe kelimeler ve Türkçeyi daha düzgün kullanabilmelerin de katkısıyla kendilerini daha iyi ifade edebildikleri görülmüştür.

Bilinçli müzik dinleyicisi olmalarına katkı sağlanarak psikolojilerini olumsuz yönde etkileyecek müziklerden uzak durmalarına katkı sağlanmıştır.

Kendilerini bir olgu/oluşuma ait hissedebilecekleri, işbirlikçi öğrenme, grupla birlikte hareket edebilme ve mücadele ruhu kazanabilecekleri çalışma ortamlarında bulunmalarına katkı sağlandığında bahsedilen hususların hepsinde gelişim gösterebildikleri görülmüştür.

Zihin-beden koordinasyonlarının gelişmesiyle odaklanma problemi ve sakarlık gibi konularda ilerleme kaydettikleri görülmüştür.

Asabilik, hırçınlık, içe kapanıklık gibi ergenlik döneminin olumsuz etkilerinde de önemli oranlarda azalmalar olduğu görülmüştür.

Yapılan çalışma sürecinde öğrencileri okul koridorunda bağlama/sazları ile gören öğretmenleri ve sınıf arkadaşlarının onlara ilettikleri beğeni ve takdir etme cümlelerinden hoşnut olan öğrenciler bu durumu çalışma arkadaşları ve araştırmacı ile birçok defa paylaşmıştır. Ayrıca çalışma sonunda düzenlenen dinleti süresince her eser sonrası ve dinleti sonunda okul idarecileri, öğretmenleri ve arkadaşları tarafından uzun süre alkışlanan öğrencilerin mutlulukları ve "başarmış olmanın" verdiği gurur ifadesi dikkat çekmiştir. Bu çalışma yoluyla öğrencilerin değer ihtiyaçları ve kendini gerçekleştirme intiyaçlarının karşılanabilmesine katkı sağlanabildiği görülmüştür.

Çalışma sonucunda elde edilen veriler ve bulgular ışığında öneriler şu şekildedir:

Kırgızistan/Bişkek örneğinde erken ergenlik dönemi içerisinde yer alan öğrenciler üzerinde olumlu kazanımların elde edildiği bu çalışma için oluşturulan bağlama/saz öğretimi ders planı ve Türk halk müziği ezgileri repertuvarı, benzer-yakın sosyal çevreye sahip ülke ve okullarda ilgili eğitimciler tarafından, kendi sosyal çevrelerine uyarlanarak kullanılabilir. 
Bu çalışma yurt dışında yaşayan "erken ergenlik dönemi" içerisinde yer alan bireyler ile gerçekleştirilmiştir. Benzer bir çalışma ergenliğin diğer bölümleri içerisinde yer alan bireyler ile de gerçekleştirilerek, elde edilen kazanımlar arasındaki benzerlik ve farklııklar incelenebilir.

Bu araştırma bağlama/saz eğitimi ve Türk halk müziği ezgileri çerçevesinde gerçekleştirilmiştir. Benzer kazanım hedeflerine sahip, Türk kültürünün bir diğer zenginliği olan klasik Türk müziği çalgısı/çalgıları ve repertuvarı yoluyla gerçekleştirilebilecek bir çalışma ile elde edilen kazanımlar arasındaki benzerlik ve farklılıklar ortaya konulabilir.

\section{Kaynaklar}

Alisinanoğlu, Fatma (2002). Gençlik Dönemi Özellikleri ve Genç Anne-Baba Illetişimi. Eğitim ve Bilim Dergisi, 2002, Cilt 27, Sayı 123 ss: 62-63

Apaydınlı, Köksal (2012). Ergenlik Dönemi Sorunlarının Çözümünde Müzik Eğitiminin Rolü ve Önemi. eJournal of New World Sciences Academy, 2012, Volume: 7, Number: 2 ss:124-130

Azizinezhad, M., Hashemi, M., Darvishi, S. (2013). Music as an Education-Related Service to Promote Learning and Skills. Procedia - Social and Behavioral Sciences, Volume: 193. Pages: 142-145

Balkıs, M., Duru, E. \& Buluş. M. (2005). Şiddete Yönelik Tutumların Öz yeterlik, Medya, Şiddete Yönelik İnanç, Arkadaş Grubu ve Okula Bağlılık Duygusu ile ilişkisi. Ege Eğitim Dergisi, Cilt: 2, Sayı: 6, s: 81-97.

Birkan, Z. I. (2014). Müzikle Tedavi, Tarihi Gelişimi Ve Uygulamaları. Ankara Akupunktur ve Tamamlayıcı Tıp Dergisi, 2014 s: 37-49

Koç, Mustafa (2004). Gelişim Psikolojisi Açısından Ergenlik Dönemi ve Genel Özellikleri. Uludağ Üniversitesi Sosyal Bilimler Enstitüsü Sosyal Bilimler Enstitüsü Dergisi, Sayı: 17 Yıl, s: 231-256.

Nişancı, İbrahim. (2013). Türkçe Şarkıların Dil Öğretiminde Kullanımı. Uluslararası Dil ve Edebiyat Çalışmaları Konferansı "Balkanlarda Türkçe" Hëna e Plotë "Beder" Üniversitesi 14-16 Kasım 2013; Tiran/Arnavutluk s: 172-179.

Oral, Arzu (2004). Ergenlik Döneminde Stresle Başa Çıkma: Stresle Başa Çıkma Programının Geliştirilmesi ve Etkililiğinin Değerlendirilmesi. Yayınlanmamış Doktora Tezi. Ankara: Ankara Üniversitesi Eğitim Bilimleri Enstitüsü.

Ökmen Burcu, Şahin Şeyma, Boyacı Zeynep, Kılıç Abdurrahman, (2019) Rekabete Dayalı Eğitim Anlayışı Bağlamında Bilgi Yarışmalarına Bakış. Eğitimde Kuram ve Uygulama-Journal of Theory and Practice in Education, 2019, 15 (3), 253-266.

Öz, Nesrin Biber (2001). İnsanın Kültürel Gelişiminde Müzik Eğitiminin Önemi, Uludağ Üniversitesi Eğitim Fakültesi Dergisi, Cilt: XIV, Sayı: 1, 101-105.

Özdemir, Osman, Özdemir, P. Güzel, Kadak, M. Tayyip, Nasıroğlu, Serhat (2012). Kişilik Gelişimi. Psikiyatride Güncel Yaklaşımlar-Current Approaches in Psychiatry, 2012; 4(4):566-589

Parlaz, E. Akçan, Tekgül Nurdan, Karademirci Emine, Öngel Kurtuluş. (2012). Ergenlik Dönemi: Fiziksel Büyüme, Psikolojik ve Sosyal Gelişim Süreci. The Journal of Turkish Family Physician, Cilt: 3, Sayı: 4, s: 10-16. 
Tekke, Mustafa ve Coşkun, Merve (2019). Kendini Tanıma, Kendini Gerçekleştirme, Kendini Aşmışlık ve Potansiyelini Tam Kullanan Kişi: Kişilerarası Iletişim. Elektronik Sosyal Bilimler Dergisi, Cilt: 18, Sayı: 70, s: 790-797.

Uçan, Ali (1996). Insan ve Müzik Insan ve Sanat Eğitimi. Ankara: Müzik Ansiklopedisi Yayınları.

Uluğbay, Selin (2013). Müzik Eğitiminin Çocuk Zekâsına Olan Etkileri. Kastamonu Eğitim Dergisi, Eylül 2013 Cilt: 21 No: 3 1025-1034

Uslu, Mustafa (2013). Müzik eğitimi aracılı̆ııyla aynı yaş gruplarının sosyokültürel değişimlerinin ve gelişimlerinin sağlanması. Inönü Üniversitesi Sanat ve Tasarım Dergisi, vol.3

Vural, G. Feyzan (2019). Yabancı Dil Olarak Türkçe Öğretiminde Müziğin Önemi. 9. Milletlerarası Türk Halk Kültürü Kongresi Bildirileri, T.C. Kültür Ve Turizm Bakanlığı Yayınları, s: 125-134.

Yıldırım, Gürkan, Bahçekapılı, Ekrem \& Bahçekapılı, Tuba (2011). Eğitimde Nitel Araştırma Yöntemleri. Durum Çalışması (Study Case), Atatürk Üniversitesi, Erzurum.

\section{Görsel Kaynakçası}

https://www.fikir.gen.tr/wpcontent/uploads/2018/06/Maslowun\%C4\%B0htiya\%C\%A7larHiyerar\%C5\%9Fisi.png 